\title{
Innovative Non-Irradiating and Non-Invasive Per Fraction Control System in Radiotherapy: Surface-Guided Radiation Therapy Experience of Casablanca Cancer Center
}

\author{
Asmaa Naim $^{1,2 *}$ (D), Safae Mansouri ${ }^{3}$ (D), Kamal Saidi ${ }^{2,4}$ (D), Redouane ElBaydaoui ${ }^{4}$ (D) , Mohamed Reda Mesradi $^{4}$ (D) \\ ${ }^{1}$ Mohammed VI University of Health Sciences (UM6SS), Casablanca, Morocco; ${ }^{2}$ Department of Radiotherapy, Casablanca \\ Cancer Center, Cheikh Khalifa Casablanca, Casablanca, Morocco; ${ }^{3}$ Department of Radiation Oncology, Oncology Center of \\ Meknes, Meknès, Morocco; ${ }^{4}$ Laboratory of Sciences and Health Technologies, Hassan First University of Settat, High Institute \\ of Health Sciences, Settat, Morocco
}

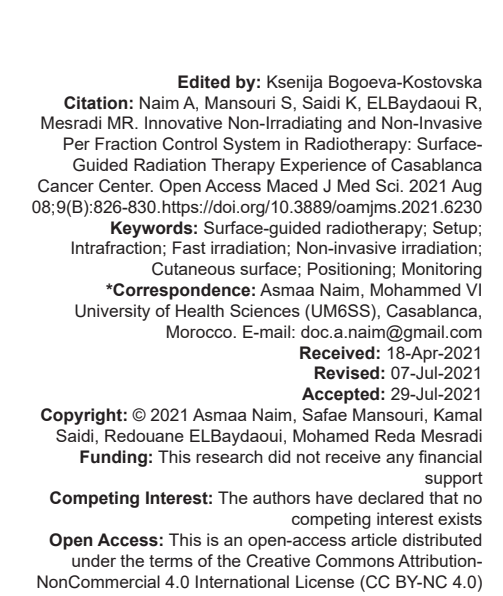

Introduction

Skin surface-guided radiotherapy (SGRT) is a relatively a new technique of radiotherapy which allows both precise positioning of patients and real-time monitoring of any possible movement during radiation delivery, based on the skin surface [1]. Indeed, SGRT is a non-invasive and non-irradiating technique because it uses infrared light detected by cameras placed in the treatment room to determine the position of the patient's skin surface. This would allow, first, precise initial positioning of the patient than the use of tattoo points alone, second, once their radiation is triggered this non-invasive system would ensure a follow-up of the patient's movements throughout the session, and finally, if the tolerance threshold of intrafractional movements is exceeded, an instantaneous stop of the irradiation beam takes place which allows an extremely safe irradiation [2]. To evaluate the added value of this new tool in practice, an observational study was carried out within our department, which involved 21 consecutive patients treated by a new generation line gas pedal dedicated to stereotaxis "True Beam Stx ${ }^{\circledR}$ " which is equipped with on-board imaging and an optical surface monitoring system (OSMS) [3]. The study consisted in a comparative analysis of the motion variability in the different spatial planes between conventional twodimensional (Kv) and/or three-dimensional (cone beam computerized tomography [CBCT]) images and the $\mathrm{OSMS}^{\circledR}$ surface monitoring data.

\section{Patients and Methods}

This is a descriptive retrospective study carried out at the Casablanca Cancer Center, which involved 21 consecutive patients treated with a gas pedal (True Beam Stx), at total of 141 radiotherapy sessions were analyzed (Table 1). The OSMS used in the study is Varian's $\mathrm{OSMS}^{\circledR}$, which uses bright light projected on the patient to determine the position of a region 
Table 1: Summary table of the main characteristics of patients and variations in their positioning in the three spatial planes

\begin{tabular}{|c|c|c|c|c|c|}
\hline & Irradiation site & $\begin{array}{l}\text { Total of } \\
\text { images }\end{array}$ & $\begin{array}{l}\text { Variation in } \\
\text { longitudinal axis } \\
\text { Médian (Min-Max) }\end{array}$ & $\begin{array}{l}\text { Variation in } \\
\text { vertical axis } \\
\text { Médian } \\
\text { (Min-Max) }\end{array}$ & $\begin{array}{l}\text { Variation in } \\
\text { lateral axis } \\
\text { Médian } \\
\text { (Min-Max) }\end{array}$ \\
\hline Case 1 & $\begin{array}{l}\text { Brain (lung } \\
\text { metastasis) }\end{array}$ & 3 & $0(0.01-0.05)$ & $\begin{array}{l}0.03 \\
(0.02-0.11)\end{array}$ & $\begin{array}{l}0.03 \\
(0.02-0.05\end{array}$ \\
\hline Case 2 & $\begin{array}{l}\text { Brain } \\
\text { (glioblastoma) }\end{array}$ & 28 & $0.2(0.17-0.22)$ & $\begin{array}{l}0.06 \\
(0.03-0.31)\end{array}$ & $\begin{array}{l}0.08 \\
(0.01-0.32\end{array}$ \\
\hline Case 3 & Head and neck & 8 & $0.01(0-0.37)$ & $\begin{array}{l}0.35 \\
(0-5.16)\end{array}$ & $\begin{array}{l}0.87 \\
(0-4.23)\end{array}$ \\
\hline Case 4 & $\begin{array}{l}{ }^{*} \text { re-irradiation } \\
\text { (medulloblastoma) }\end{array}$ & 4 & $0(0-0.01)$ & $\begin{array}{l}0.005 \\
(0-0.03)\end{array}$ & $\begin{array}{l}0.01 \\
(0-0.02)\end{array}$ \\
\hline Case 5 & $\begin{array}{l}\text { Brain (rectal } \\
\text { metastasis) }\end{array}$ & 3 & $0.01(0-0.12)$ & $\begin{array}{l}0.01 \\
(0-0.13)\end{array}$ & $\begin{array}{l}0.01 \\
(0-0.07)\end{array}$ \\
\hline Case 6 & $\begin{array}{l}\text { Brain (lung } \\
\text { metastasis) }\end{array}$ & 3 & $0.01(0-0.01)$ & $0(0-0.02)$ & $0(0-0)$ \\
\hline Case 7 & $\begin{array}{l}\text { Brain (lung } \\
\text { metastasis) }\end{array}$ & 3 & $0(0-0.02)$ & $0(0-0.09)$ & $\begin{array}{l}0.02 \\
(0-0.04)\end{array}$ \\
\hline Case 8 & $\begin{array}{l}\text { Brain* } \\
\text { (pineocytoma) }\end{array}$ & 4 & $0.035(0-8)$ & $\begin{array}{l}0.045 \\
(0.01-11.78)\end{array}$ & $\begin{array}{l}0.05 \\
(0-5.19)\end{array}$ \\
\hline Case 9 & $\begin{array}{l}\text { Brain (breast } \\
\text { metastasis) }\end{array}$ & 5 & $0.01(0-0.01)$ & $\begin{array}{l}0.02 \\
(0.01-0.04)\end{array}$ & $0(0-0.01)$ \\
\hline Case 10 & $\begin{array}{l}\text { Brain* (breast } \\
\text { metastasis) }\end{array}$ & 2 & $0.405(0.02-0.79)$ & $\begin{array}{l}1.1 \\
(0.04-2.16)\end{array}$ & $\begin{array}{l}0.565 \\
(0.01-1.12\end{array}$ \\
\hline Case 11 & $\begin{array}{l}\text { Brain (lung } \\
\text { metastasis) }\end{array}$ & 2 & $0(0-0)$ & $\begin{array}{l}0.035 \\
(0.01-0.06)\end{array}$ & $\begin{array}{l}0.005 \\
(0-0.01)\end{array}$ \\
\hline Case 12 & $\begin{array}{l}\text { Brain (breast } \\
\text { metastasis) }\end{array}$ & 4 & $0.005(0-0.01)$ & $\begin{array}{l}0.02 \\
(0.01-0.04)\end{array}$ & $0(0-0.01)$ \\
\hline Case 13 & $\begin{array}{l}\text { Vertebral } \\
\text { metastasis }\end{array}$ & 4 & $0.145(0.03-0.46)$ & $\begin{array}{l}3.505 \\
(0.02-8.09)\end{array}$ & $\begin{array}{l}0.14 \\
(0.09-0.21\end{array}$ \\
\hline Case 14 & $\begin{array}{l}\text { Brain (colorectal } \\
\text { metastasis) }\end{array}$ & 7 & $0.02(0-0.03)$ & $\begin{array}{l}0.04 \\
(0-0.07)\end{array}$ & $\begin{array}{l}0.01 \\
(0-0.02)\end{array}$ \\
\hline Case 15 & Head and neck & 14 & $0.02(0-2.81)$ & $\begin{array}{l}0.02 \\
(0-1.64)\end{array}$ & $\begin{array}{l}0.02 \\
(0-0.6)\end{array}$ \\
\hline Case 16 & Head and neck & 31 & $0.03(0-0.13)$ & $\begin{array}{l}0.02 \\
(0-0.09)\end{array}$ & $\begin{array}{l}0.01 \\
(0-0.15)\end{array}$ \\
\hline Case 17 & Head and neck* & 4 & $0.03(0.02-0.04)$ & $\begin{array}{l}0.025 \\
(0.01-0.08)\end{array}$ & $\begin{array}{l}0.025 \\
(0-0.03)\end{array}$ \\
\hline Case 18 & $\begin{array}{l}\text { Brain* } \\
\text { (glioblastoma) }\end{array}$ & 3 & $0.03(0.02-0.11)$ & $\begin{array}{l}0.06 \\
(0.06-0.11)\end{array}$ & $\begin{array}{l}0.04 \\
(0.03-0.09\end{array}$ \\
\hline Case 19 & $\begin{array}{l}\text { Vertebral } \\
\text { metastasis }\end{array}$ & 5 & $0.01(0-5.82)$ & $\begin{array}{l}0.02 \\
(0-7.32)\end{array}$ & $\begin{array}{l}0.01 \\
(0-5.71)\end{array}$ \\
\hline Case 20 & Brain (metastasis) & 3 & $0.03(0.03-0.46)$ & $\begin{array}{l}0.04 \\
(0.04-0.09)\end{array}$ & $\begin{array}{l}0.17 \\
(0.16-0.17\end{array}$ \\
\hline Case 21 & Brain (metastasis) & 3 & $0.05(0.01-0.07)$ & $\begin{array}{l}0 \\
(0.09-0.02)\end{array}$ & $\begin{array}{l}0.01 \\
(0.01-0.02\end{array}$ \\
\hline
\end{tabular}

of interest on the patient's surface [3]. In this study, the total session time and positioning variability were reported.

Positioning variability was compared between conventional imaging and infrared skin surface monitoring $\left(\mathrm{OSMS}^{\circledR}\right)$. Conventional imaging was in the form of either standard radiography (KV) performed during the treatment session or three-dimensional imaging by a CBCT [4].

\section{Inclusion criteria}

The following criteria were included in the study:

Patients treated with a gas pedal dedicated to stereotactic radiotherapy "True Beam ${ }^{\circledR}$."

- $\quad$ Monitoring by optical surface system "OSMS ${ }^{\circledR}$."

- $\quad$ Control by radiological imaging (image-guided radiation therapy [IGRT]).

\section{Exclusion criteria}

Treatments controlled exclusively by radiological imaging (IGRT).

\section{Results}

The variation of the positioning parameters in the three basic planes of space was inframillimetric with a median in longitudinally of $0.02 \mathrm{~mm}(0-0.4)$, in verticality $0.02 \mathrm{~mm}(0-3.5 \mathrm{~mm})$, and in laterality $0.02 \mathrm{~mm}(0-0.87)$ (Figures 1-3), While the median of the variations in rotational movements were $<0.5^{\circ}$. Skin surface monitoring resulted in faster patient alignment with a significant gain in overall session time, with a median gain of $32 \%$.

\section{Discussion}

Radiotherapy is a major therapeutic weapon in oncology. It has made great strides forward, allowing for more precise treatment that better targets tumor volumes and spares as many healthy neighboring organs as possible [5]. Indeed, the area of conventional two-dimensional radiotherapy based on bone markers has given way to conformal radiotherapy using three-dimensional imaging and thus irradiation of volumes. Subsequently, the computer revolution made it possible to modulate the irradiation beam and gave birth to conformal radiotherapy with intensity modulation, which is not conceivable without threedimensional imaging at the time of treatment, thus giving rise to IGRT [6].

Although IGRT allows a precise and safe irradiation, it exposes, on the one hand, to an additional dose of radiation and, on the other hand, does not take into account possible intrafraction movements [7]. SGRT, which is a non-invasive and above all nonirradiating tool, is part of the innovative trajectory of radiotherapy, essentially allowing monitoring of the patient's movements during irradiation with the added advantage of instantaneous stopping of the irradiation beam if the movements exceed the authorized tolerance threshold, thus providing highly precise and extremely reliable irradiation [8]. To verify the added value of skin surface-guided radiotherapy in our practice, we analyzed 141 radiotherapy sessions by comparing the shifts obtained by the available "OSMS" surface monitoring and the usual radiological images, either conventional (Kv) or three dimensional (CBCT). Wagner et al. [9] have demonstrated that during intracranial stereotactic radiotherapy, surface imaging allows to obtain an inframillimetric precision. Similarly, other team shave reported their experience [10], [11] with almost similar results between the use of a stereotactic frame and the window mask combined with an SGRT technique, with a concordance of about $1 \mathrm{~mm} / 1^{\circ}$. The use of SGRT to treat intracranial lesions has led to its application 


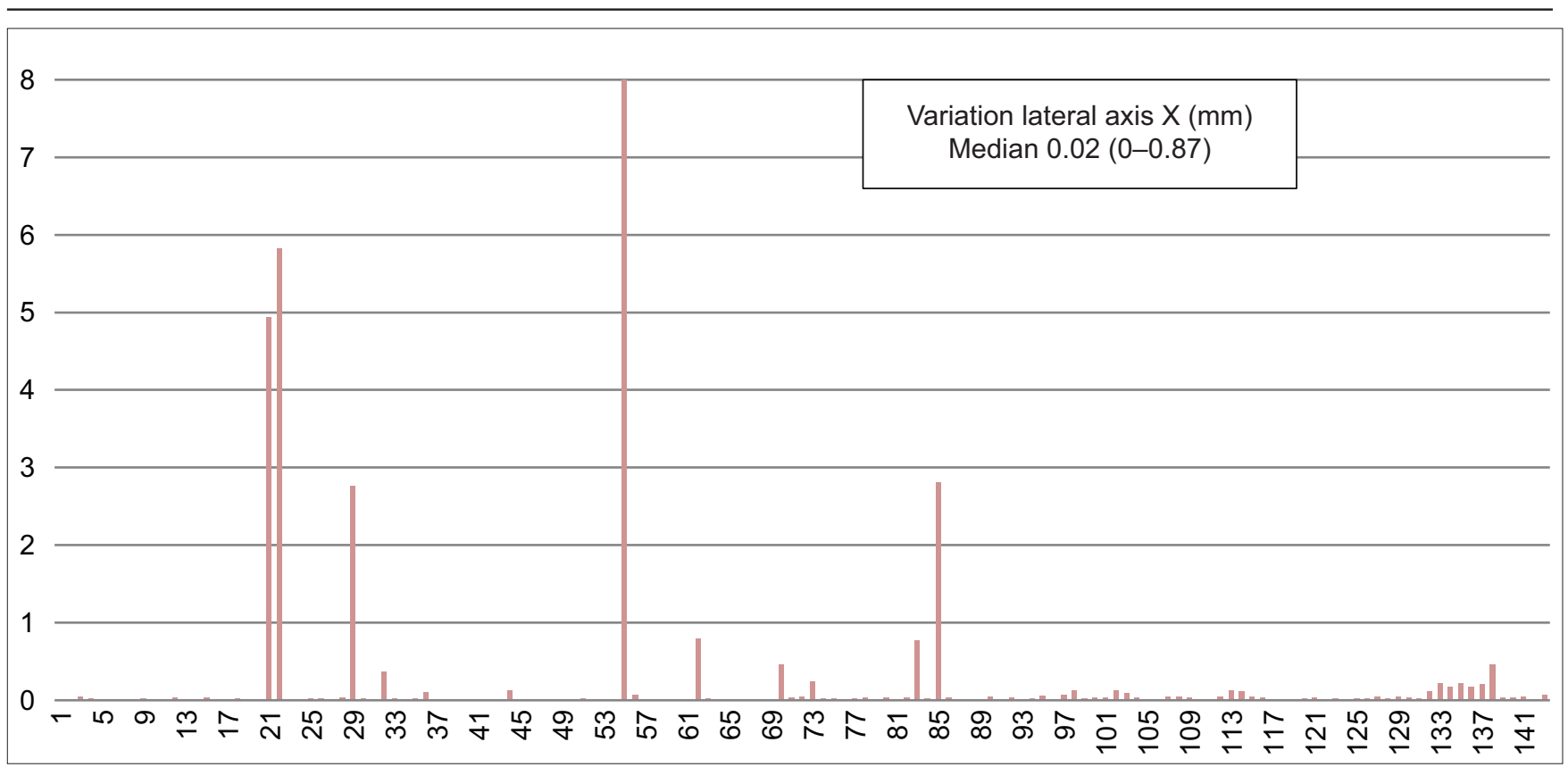

Figure 1: The variation of the positioning parameters in the lateral axis $(x)$

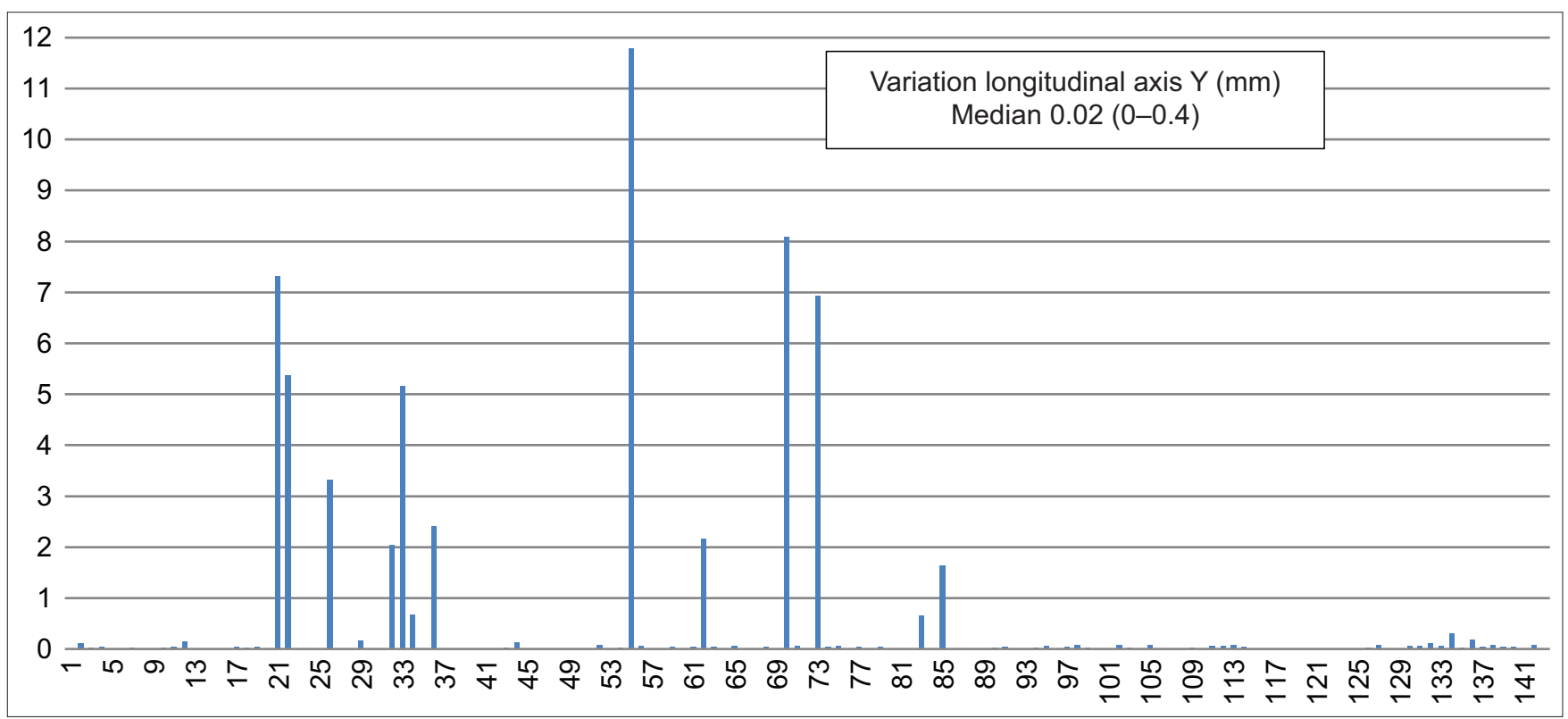

Figure 2: The variation of the positioning parameters in the longitudinal axis (y)

to the treatment of head-and-neck cancers [12]. It is usual, in case of otolaryngology irradiation, to make a thermoformed mask to immobilize patients. As SGRT requires direct visualization of the patient's skin, the use of a windowed mask is essential [13]. To ensure reproducibility of the treatment, Li et al. [14] demonstrated that an open mask offers immobility comparable to closed masks with movements with a mobility in the six planes of space of about $1 \mathrm{~mm} / 1^{\circ}$. The results of our study agree with those of the literature with inframillimeter averages, all locations combined [15]. However, we have noted that the accuracy of surface monitoring is relatively poorer in extracranial locations [16]. This could be explained by the respiratory movements that indirectly influence the position of the skin surface in both thoracic and abdominal-pelvic locations. Nevertheless, several studies [17], [18] have suggested that there is a correlation between internal movements and skin surface, which may reduce planning target volume margins and thus allow more targeted irradiation [19]. Furthermore, data from our study show that surface monitoring saves time in the treatment room [20] with a considerable reduction in the average session duration of $32 \%(14.5-49.27 \%)$. This time saving became even more important as the expertise of the manipulators increased. 


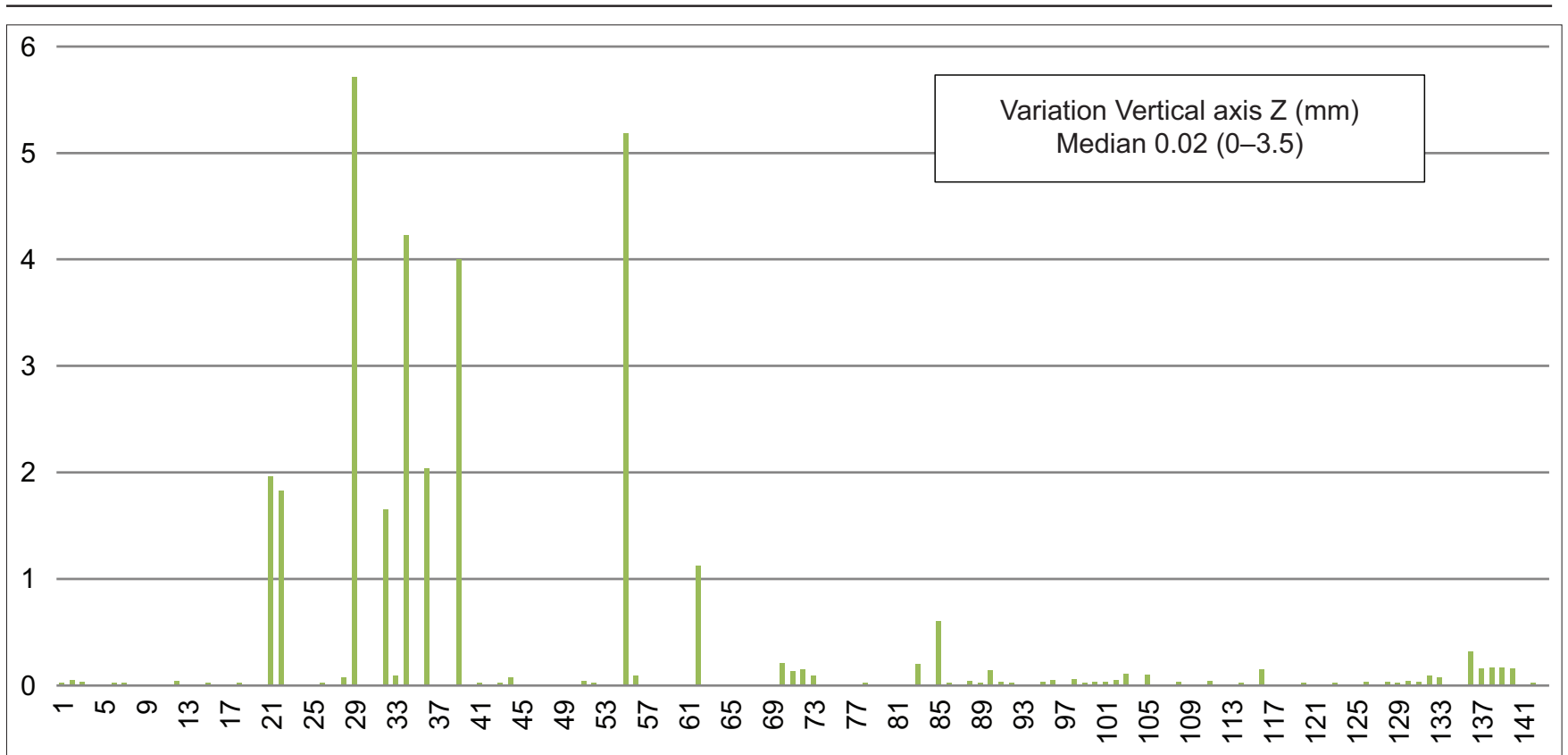

Figure 3: The variation of the positioning parameters in the vertical axis (z)

\section{Conclusion}

The optical surface monitoring system is a noninvasive and non-irradiating means, complementary to conventional IGRT means, which allows realtime intrafraction monitoring with instantaneous stop of the irradiation beam and thus reliable and fast irradiation [21].

\section{References}

1. Brahme A, Nyman P, Skatt BB. 4D laser camera for accurate patient positioning, collision avoidance, image fusion and adaptive approaches during diagnostic and therapeutic procedures. Med Phys. 2008;35(5):1670-81. https://doi. org/10.1118/1.2889720

PMid:18561642

2. Hoisak JD, Pawlicki T. The role of optical surface imaging systems in radiation therapy. Semin Radiat Oncol. 2018;28(3):185-93. PMid:29933878

3. Lewis BC, Snyder WJ, Kim S, Kim T. Monitoring frequency of intra-fraction patient motion using the ExacTrac system for LINAC-based SRS treatments. J Appl Clin Med Phys. 2018;19(3):58-63. https://doi.org/10.1002/acm2.12279 PMid:29577592

4. Pycinski B, Czajkowska J, Badura P, Juszczyk J, Pietka E. Timeof-flight camera, optical tracker and computed tomography in pairwise data registration. PLoS One. 2016;11(7):e0159493. https://doi.org/10.1371/journal.pone.0159493

PMid:27434396

5. Stanley DN, Mcconnell KA, Kirby N, Gutiérrez AN, Papanikolaou N, Rasmussen K. Comparison of initial patient setup accuracy between surface imaging and three point localization: A retrospective analysis. J Appl Clin Med Phys. 2017;18(6):58-61. https://doi.org/10.1002/acm2.12183

\section{PMid:28901684}

6. Wikström K, Nilsson K, Isacsson U, Ahnesjö A. A comparison of patient position displacements from body surface laser scanning and cone beam CT bone registrations for radiotherapy of pelvic targets. Acta Oncol (Madr). 2014;53(2):268-77. https://doi.org/1 $0.3109 / 0284186 \times .2013 .802836$

PMid:23786175

7. Murphy MJ, Balter J, Balter S, Jiang SB. The management of imaging dose during image-guided radiotherapy: Report of the AAPM task group 75. Med Phys. 2007;34(10):4041-63. https:// doi.org/10.1118/1.2775667

PMid: 17985650

8. Carl G, Reitz D, Schönecker S, Pazos M, Freislederer P, Reiner $\mathrm{M}$, et al. Optical surface scanning for patient positioning in radiation therapy: A prospective analysis of 1902 fractions. Technol Cancer Res Treat. 2018;17:1533033818806002. https://doi.org/10.1177/1533033818806002 PMid:30453842

9. Wagner TH, Meeks SL, Bova FJ, Friedman WA, Willoughby TR, Kupelian PA, et al. Opticaltracking technology in stereotactic radiation therapy. Med Dosim. 2007;32(2):111-20. https://doi. org/10.1016/j.meddos.2007.01.008 PMid: 17472890

10. Cerviño LI, Pawlicki T, Jiang SB, Lawson JD. Frame-less and mask-less cranial stereotactic radiosurgery: A feasibility study. Phys Med Biol. 2010;55(7):1863-73. https://doi. org/10.1088/0031-9155/55/7/005

PMid:20224158

11. Wiersma RD, Tomarken SL, Grelewicz Z, Belcher AH, Kang H Spatial and temporal performance of 3D optical surface imaging for real time head position tracking. Med Phys. 2013;40(11):111712. https://doi.org/10.1118/1.4823757 PMid:24320420

12. Tarnavski N, Engelholm SA, Af Rosenschold PM. Fast intrafractional image guidance with $6 \mathrm{D}$ positioning correction reduces delivery uncertainty for stereotactic radiosurgery and radiotherapy. J Radiosurg SBRT. 2016;4(1):15-20. https://doi. org/10.1016/s0167-8140(15)40772-8 PMid:29296422

13. Zhao B, Maquilan G, Jiang S, Schwartz DL. Minimal mask 
immobilization with optical surface guidance for head and neck radiotherapy. J Appl Clin Med Phys. 2018;19(1):17-24. https:// doi.org/10.1002/acm2.12211

PMid:29119677

14. Li G, Lovelock DM, Mechalakos J. Migration from full-head mask to"open-face"mask for immobilization of patients with head and neck cancer. J Appl Clin Med Phys. 2013;14(5):243-54. https:// doi.org/10.1120/jacmp.v14i5.4400

PMid:24036878

15. Covington EL, Fiveash JB, Wu X, Brezovich I, Willey CD, Riley K, et al. Optical surface guidance for submillimeter monitoring of patient position during frameless stereotactic radiotherapy. J Appl Clin Med Phys. 2019;20(6):91-8. https://doi.org/10.1002/ acm2.12611

PMid:31095866

16. Reitz D, Carl G, Schönecker S, Pazos M, Freislederer $P$, Niyazi $M$, et al. Realtime intra-fraction motion management in breast cancer radiotherapy: Analysis of 2028 treatment sessions. Radiat Oncol. 2018;13(1):128. https://doi.org/10.1186/ s13014-018-1072-4

PMid:30012156

17. Schaerer J, Fassl A, Riboldi M, Cerveri P, Baroni G, Sarrut D. Multi-dimensional respiratory motion tracking from markerless optical surface imaging based on deformable mesh registration. Phys Med Biol. 2012;57(2):357-73. https://doi. org/10.1088/0031-9155/57/2/357

PMid:22170786

18. Aznar MC, Maraldo MV, Schut DA, Lundemann M, Brodin NP, Vogelius IR, et al. Minimizing late effects for patients with mediastinal Hodgking lymphoma: Deep inspiration breath hold, IMRT, or both? Int J Radiat Oncol Biol Phys. 2015;92(1):196-74. https://doi.org/10.1016/j.jrobp.2015.01.013 PMid:25754634

19. Haraldsson A, Ceberg S, Crister C, Engelholm S, Bäck SÅ, Engström PE. PO0978 accurate positioning with decreased treatment time using surface guided tomotherapy. Radiother Oncol. 2019;133:S534-5. https://doi.org/10.1016/ s0167-8140(19)31398-2

20. Willoughby T, Lehmann J, Bencomo JA, Jani SK, Santanam L, Sethi A, et al. Quality assurance for nonradiographic radiotherapy localization and positioning systems: report of task group 147. Med Phys. 2012;39(4):1728-47. https://doi. org/10.1118/1.3681967

PMid:22482598

21. Freislederer $P$, Kügele $M$, Öllers $M$, Swinnen $A$, Sauer TO, Bert $\mathrm{C}$, et al. Recent advanced in surface guided radiation therapy. Radiat Oncol. 2020;15:187. https://doi.org/10.1186/ s13014-020-01661-w

PMid:32736570 